\title{
Keragaan Galur Padi Lahan Sawah Pasang Surut Type C Melalui Teknologi Ratun Kabupaten Rokan Hilir
}

\author{
The Performance of the C Type of Swamp Rice Line Through Ratoon Technology \\ at Rokan Hilir Regency
}

\author{
Emi Sari Ritonga ${ }^{1 *}$, Ida Nur Istina ${ }^{1}$, Maizar Maizar ${ }^{2}$ \\ ${ }^{1}$ Balai Pengkajian Teknologi Pertanian Riau, Kota Pekanbaru, Riau 28284 \\ ${ }^{2}$ Universitas Islam Riau, Kota Pekanbaru, Riau 28284 \\ ${ }^{*}$ Penulis untuk korespondensi: emisaribptp@gmail.com
}

(diterima 11 Juni 2019, disetujui 9 Oktober 2019)

Sitasi: Ritonga ES, Istina IN, Maizar M. 2019. The performance of the C Type of swamp rice line through ratoon technology at Rokan Hilir Regency. Jurnal Lahan Suboptimal: Journal of Suboptimal Lands. 8(2): $220-229$

\begin{abstract}
To support food security, the government set a national rice production target of 10 million tons in 2014. Its a trigger in agricultural innovation. The utilization of sub-optimal lands such as tidal lowland for the purpose of increasing food production and selfsufficiency and making swamps as a national food barn continue to be pursued, both through innovation and excavation and the development of local wisdom. Various technological innovations have been produced by the IAARD on tidal lowland, including increasing crop intensity (IP), genetic improvement in rice, and ratoon planting systems. The aim of this research was to get the type $C$ tidal rice lines through ratoon technology. The research has been conducted at Pematang Sikek Village, Rimbo Melintang sub District, Rokan Hilir Regency with $\mathrm{C}$ type of tidal lowland using a Randomized Group Design with 4 replications. The rice strains tested included 11 tidal rice were with 11 types of tidal rice lines (G1, G3, G4, G6, G7, G8, G17, G20, G23, G45, G53). The results showed that the best vegetative growth were G3 $(118.33 \mathrm{~cm})$, G7 $(15.00$ stems $)$. Number of productive tillers was G4 (15.33 stems) while for generative growth G4 (2.50 ton/ha), G53 ratoon $(35.33 \mathrm{~cm}) 238.00 \mathrm{~g})$, weight of a thousand grains of G53 ratoon was $(26.77$ g). G4 gives the highest production and adapted to Rokan Hilir tidal lowland.
\end{abstract}

Keywords: rice, ratoon, tidal lowland

\begin{abstract}
ABSTRAK
Untuk mendukung ketahanan pangan pemerintah telah menetapkan target Produksi beras Nasional sebesar 10 juta ton pada tahun 2014. Hal ini menjadi pemicu dalam inovasi pertanian. Pemanfaatan lahan-lahan sub optimal seperti lahan pasang surut untuk tujuan meningkatkan produksi dan swasembada pangan serta menjadikan lahan rawa sebagai lumbung pangan nasional, terus diupayakan, baik melalui inovasi maupun penggalian dan pengembangan kearifan lokal. Berbagai inovasi teknologi telah dihasilkan Badan Litbang Pertanian di lahan pasang surut, diantaranya peningkatan intensitas pertanaman (IP), perbaikan genetik padi, dan sistem tanam ratun. Penelitian bertujuan mendapatkan galur padi lahan sawah pasang surut type $\mathrm{C}$ melalui teknologi ratun. Penelitian dilaksanakan Desa Pematang Sikek Kecamatan Rimbo Melintang Kabupaten RokanH ilir yang
\end{abstract}


merupakan lahan pasang surut dengan tipologi lahan $\mathrm{C}$ dari bulan Maret sampai dengan bulan Juli 2014 menggunakan Rancangan Acak Kelompok dengan 4 kali ulangan. Galur padi yang diuji meliputi 11 galur padi pasang surut yaitu G1, G3, G4, G6, G7, G8, G17, G20, G23, G45, dan G53. Parameter yang diamati adalah: tinggi tanaman, jumlah anakan, jumlah anakan produktif, umur berbunga, panjang malai, jumlah biji bernas, berat 1000 butir, ubinan. Hasil penelitian menunjukkan bahwa pada pertumbuhan vegetative adalah G3 (118.33 cm), G7 (15.00 batang) Jumlah anakan produktif G4 (15.33 batang) sedangkan untuk pertumbuhan generative hasil G4 (2.50 ton/ha), panjang malai G53 $(35.33 \mathrm{~cm})$, gabah bernas G17 (238.00 g), berat seribu butir tanaman G53 (26,77 g). G4 memberikan hasil yang tertinggi (2,50 ton/ha) dan dapat beradaptasi terhadap lingkungan lahan pasang surut Kabupaten Rokan Hilir.

Kata kunci: padi, ratun, sawah pasang surut

\section{PENDAHULUAN}

Untuk mendukung ketahanan pangan, pemerintah telah menetapkan target produksi beras Nasional sebesar 10 juta ton pada tahun 2014. Hal ini menjadi pemicu dalam mendapatkan inovasi baru, untuk mendukung langkah nyata dalam upaya pencapaian swasembada pangan berkelanjutan. Pemanfaatan lahan-lahan sub optimal seperti lahan rawa pasang surut sebagai areal pengembangan berkaitan dengan semakin berkurangnya lahan potensial terus diupayakan dengan berbagai cara, baik melalui inovasi maupun penggalian dan pengembangan kearifan lokal.

Lahan pasang surut memiliki karakteristik yang khas, yaitu 1) sumber air ditentukan oleh kondisi pasang dan surutnya air sungai, 2) tanahnya bereaksi masam sampai sangat masam, 3) mempunyai lapisan pirit (FeS2) yang merupakan sumber racun besi bagi tanaman, tanahnya miskin hara dengan heterogenitas yang sangat tinggi sehingga bervariasi dari satu lokasi ke lokasi lainnya. Anwar et al. (2001), menyebutkan lahan pasang surut biasanya dicirikan oleh: (1). $\mathrm{pH}$ tanah rendah, (2). Genangan yang dalam, (3). Akumulasi zat-zat beracun (besi dan aluminium), (4). Salinitas tinggi, dan (5) kekurangan unsur hara, namun berpotensi sebagai lumbung pangan nasional Arsyad et al, (2014).
Indonesia mempunyai lahan pasang surut diperkirakan seseluas 24.7 juta hektar terdapat di daerah Sumatera, Kalimantan, dan Irian Jaya, sedangkan 9,53 juta ha diantaranya berpotensi di kembangkan untuk pertanian. Dari 9,53 juta ha tersebut, 6 juta ha berpotensi untuk area tanaman pangan (Dakhyar et al., 2012), dengan demikian lahan pasang surut seyogianya dapat menjadi sentra produksi padi diindonesia. Tetapi keterbatasan tenaga kerja dan infrastruktur menyebabkan pengembangan lahan pasang surut belum optimal.

Namum demikian, rata-rata hasil panen dari lahan pasang surut 3-4 ton/ha GKP pemanfaatan belum optimal. Di Provinsi Riau setidaknya terdapat 24.982.03 ha lahan pasang surut yang tersebar di Kabupaten Indragiri Hilir, Siak, Pelalawan dan Rokan Hilir (BPS, 2011).

Provinsi Riau merupakan salah satu provinsi yang potensial untuk pengembangan padi sawah karena terdapat lahan yang cukup luas, baik lahan sawah berpengairan maupun lahan sawah pasang surut. Menurut Laporan Tahunan Dinas Pertanian Tanaman Pangan dan Hortikultura Provinsi Riau (2011), terdapat 96.000 ha sawah berpengairan tetapi yang telah dimanfaatkan untuk usaha budidaya padi hanya seluas 43.000 ha sementara lahan pasang surut yang potensial dijadikan sawah seluas 240.000 ha. Provinsi Riau mempunyai lahan sawah potensial cukup 
luas tetapi masih kekurangan beras 300.000 ton per tahun karena produksi padi baru mencapai 350.000 ton per tahun, sedangkan konsumsi mencapai 650.000 ton per tahun.

Berbagai inovasi teknologi lahan pasang surut telah dihasilkan Badan Litbang Pertanian diantaranya peningkatan intensitas pertanaman (IP) melalui inovasi teknologi Ratun. Ratun atau Singgang (Jawa) atau Turiang (Sunda), Salibu (Sumatera Barat), Coding (Rokan Hilir), Suli (Sumatera Utara) merupakan pemotongan sisa panen atau tunggul yang dilakukan di atas permukaan tanah. Keuntungan penerapan ratun adalah cepat, mudah serta dapat meningkatkan produktivitas padi per unit area dan per unit waktu, karena tanaman ratun memiliki durasi pertumbuhan pendek dibandingkan dengan tanaman utama (Oad and Cruz, 2002). Selain itu inovasi teknologi ratun memberikan keuntungan melalui 1) biaya produksi lebih murah, karena tidak ada biaya pengolahan tanah dan tanam, 2) pupuk yang diperlukan lebih sedikit dibandingkan tanaman utama, yaitu hanya setengah dari dosis tanaman utama dan dapat diberikan hanya urea saja, 3) umur lebih pendek yaitu berkisar antara 40-45 hari setelah panen tanaman utama, 4) hasil dapat mencapai 40\%-60\% dari tanaman utama atau produksi yang bervariasi antara 0,7-5,6 ton/ha, 5) meningkatkan produktivitas padi per musim tanam, 6) meningkatkan indeks panen per musim tanam dari sekali menjadi dua kali panen per musim. Hal ini seiring dengan pendapat Susilowati dan Purwoko (2012) bahwa teknologi ratun adalah teknologi yang hemat dalam hal modal faktor produksi, lebih cepat panen dan bersifat ramah lingkungan, dapat menekan kebiasaan petani untuk membakar jerami setelah panen (Erdiman et al., 2013). Menurut Abdullah et al. (2015) penerapan teknologi ini juga dapat menekan kebutuhan benih per satuan lahan.

Hasil ratun yang masih rendah dapat disebabkan oleh varietas yang tidak memiliki kemampuan genetik ratun yang baik atau perlakuan budidaya yang kurang tepat. Oleh karena itu seleksi genotipegenotipe berpotensi ratun perlu dilakukan dan harus didukung dengan teknik budidaya yang benar. Teknologi ratun yang sudah diperbaiki dapat dijadikan solusi bagi petani pasang surut yang masih enggan melaksanakan penanaman lebih dari dua kali setahun sehingga mereka tetap dapat berpartisipasi dalam program peningkatan produksi beras Nasional. Secara visual tunas ratun dari tinggi pemotongan $10 \mathrm{~cm}$ di atas tanah mulai muncul pada hari kedua setelah panen, sedangkan pada tinggi pemotongan $20 \mathrm{~cm}$ dan $30 \mathrm{~cm}$, ratun mulai muncul pada hari keempat. Daun ratun mulai membuka pada hari kelima dan hamper sama pada semua tinggi pemotongan.

Umur tanaman ratun yang lebih pendek dibandingkan tanaman utama, erat hubungannya dengan pola pertumbuhan tanaman padi yang berasal dari benih atau bibit. Pada tanaman utama terdapat tiga fase pertumbuhan, yaitu fase vegetatif, reproduktif dan pemasakan. Namun untuk tanaman ratun yang sejak keluar anakan sering diikuti juga keluarnya bunga, hanya mengalami dua fase pertumbuhan,yaitu fase reproduktif dan pemasakan. Kedua fase ini umumnya berlangsung sama pada semua genotipe padi,yaitu selama 35 hari untuk fase reproduktif dan 30 hari untuk fase pemasakan sehingga umur tanaman ratun akan berada pada kisaran 65 hari saja (Vergara, 1995).

Padi ratun agar lebih produktif harus dilakukan pemeliharaan secara intensif, diantaranya pengolahan lahan, pengairan, penyiangan, pemupukan dan pengendalian pengganggu yang berupa hama, penyakit atau gulma. Budidaya ratun dapat meningkatkan indeks panen dari 2 sampai 3 bahkan bisa 4 kali panen dalam 1 tahun. Pada sistem ratun diperlukan pemotongan batang jerami padi. Pemotongan batang jerami bertujuan untuk memunculkan tunas dari buku yang ada di dalam tanah. Tunas 
akan mengeluarkan akar baru sehingga suplay hara tidak lagi tergantung pada batang lama, tunas dapat membelah atau bertunas lagi seperti padi tanaman pindah biasa, sehingga membuat pertumbuhan dan produksinya sama atau lebih tinggi dibanding tanaman pertama. Pertumbuhan tunas setelah dipotong sangat dipengaruhi oleh ketersediaan air.

\section{BAHAN DAN METODE}

Penelitian telah dilaksanakan Desa Pematang Sikek Kecamatan Rimbo Melintang Kabupaten Rokan Hilir dengan tipe luapan C dari bulan Maret sampai dengan bulan Juli 2014. Bahan yang digunakan 11 jenis galur padi pasang surut (G1, G3, G4, G6, G7, G8, G17, G20,G23, G45, G53), pupuk dasar Urea $100 \mathrm{~kg} / \mathrm{ha}$, TSP 150 kg/ha, KCl 50 kg/ha, Furadan 16 $\mathrm{kg} / \mathrm{ha}$, dolomit, pupuk kandang (1 ton/ha), herbisida, pestisida. Alat yang digunakan adalah cangkul, parang babat, sabit, gunting, bagan warna daun, plastik pagar, tali, kantong plastik, perangkap tikus, karung, timbangan digital, timbangan 10 $\mathrm{kg}$, meteran, moisture tester, kamera, dan alat tulis. Penelitian dilapangan menggunakan Rancangan Acak Kelompok (RAK) dengan Kali ulangan. Parameter yang diamati meliputi: Jumlah tunas ratun yang tumbuh satu bulan setelah panen. Tinggi tanaman ratun $(\mathrm{cm})$, Jumlah ratun produktif (batang), Jumlah biji bernas per malai (butir), Bobot 1000 butir (g), dan Hasil panen padi ratun (ton/ha), Data yang terkumpul ditabulasikan dan dianalisis secara statistika. Luas setiap petak perlakukan berukuran $5 \mathrm{~m}$ x $5 \mathrm{~m}$, jarak antar petak $0.5 \mathrm{~m}$.). Tahapan penelitian melakukan pengambilan sampel tanah, persemaian, pemupukan, penanaman pada umur semai 14 hari di persemaian.

\section{HASIL DAN PEMBAHASAN}

Hasil penelitian menunjukkan bahwa keragaan galur padi sawah lahan pasang surut type $\mathrm{C}$ melalui teknologi ratun yang berpengaruh nyata terhadap terjadinya berbedaan pada tinggi tanamanan pada G3,G6,G23 (11,33 cm) terendah G4 $(103,33 \mathrm{~cm})$, jumlah anakan tertinggi G7 $(15,00)$ terendah G1 $(7,67)$, anakan produktif terbanyak G4 $(55,33)$ terendah G1 $(5,67)$ dan umur berbunga tertinggi pada G45 (80 hari) terendah G53 (71,00 hari), panen tertinggi G45 (114) hari terendah G1 (103 hari) (Tabel 1).

Berbagai galur yang diuji pada lahan pasang surut lokasi kajian tidak berbeda secara nyata. Hal ini menunjukkan bahwa galur yang diuji memiliki kesesuaian tempat tumbuh dan ketersediaan hara yang diperlukan untuk metabolismenya. Tinggi tanaman pada ratun berbagai galur tertinggi $(118,33 \mathrm{~cm})$ terdapat pada Galur G 3, G 6 dan $\mathrm{G} 45$ dan terendah $105 \mathrm{~cm}$ ditunjukkan oleh galur G1.

Tinggi tanaman merupakan karakter agronomis yang penting dalam seleksi galur padi lahan pasang surut dengan tipe genangan tinggi. Tanaman yang rendah kurang sesuai ditanam di lahan pasang surut, karena genangan air yang tinggi dapat menyebabkan pertumbuhan tanaman padi terhambat dan mati (Sutami, 2004). Meskipun demikian faktor tinggi dan rendah tanaman bukanlah menjadi ukuran dalam menentukan daya hasil suatu Galur padi. Tetapi variable tinggi tanaman utama diharapkan akan diikuti oleh ratun. Dalam budidaya ratun diharapkan tanaman ratun yang dihasilkan berbatang tinggi sehinga malai yang dihasilkan akan lebih panjang. Diperlukan galur yang tinggi batangnya ideal untuk menghasilkan ratun yang ideal. Interaksi $\mathrm{G}$ x $\mathrm{E}$ yang nyata menunjukkan adanya perbedaan tanggapan genotip yang diuji pada lingkungan yang berbeda

Penurunan hasil panen pada percobaan yang digenangi terus menerus tanah lebih hypoxic. Genangan terus menerus di area sawah menyebabkan Fe (II) diserap sampai kedaun tanaman sehingga terbentuk reaksi oksigen spesies, Keracunan besi dapat menurunkan tinggi tanah korelasinya 
hanya 0,14 . Hal ini menunjukkan tanaman utama yang berdaya hasil tinggi tidak selalu menghasilkan ratun yang berdaya hasil tinggi pula.Namun terdapat peluang untuk memperoleh genotip yang hasil tanaman utama dan ratunnya sama-sama tinggi melalui seleksi (Mishra dan Salokhe, 2010)

Dengan pemilihan genotip dan teknologi budidaya yang tepat, ratun menghasilkan lebih dari 4 ton/ha GKG atau lebih 50\% dari hasil tanaman utama (Liu et al., 2012). Dari tanaman utama yang hasil gabahnya
5,0-7,3 ton/ha di peroleh ratun dengan hasil yang berkisar antara 1,0-4,7 ton/ha gabah atau hasil ratun dapat mencapai $64 \%$ dari hasil tanaman utama (Adigbo et al., 2012). Tidak semua varietas padi dapat menghasilkan ratun yang baik. Ada peluang untuk memperbaiki potensi padi ratun sehingga hasil dari tanaman kedua dapat mendekati hasil tanaman utama, melalui perbaikan genotip dan memilih lingkungan tumbuh yang sesuai untuk produksi ratun (Liu et al., 2011).

Tabel 1. Keragaan vegetative galur-galur pada tanaman tinggi tanaman (cm), jumlah anakan (anakan/rumpun), jumlah anakan produktif (anakan/rumpun), umur berbunga (hst)

\begin{tabular}{|c|c|c|c|c|c|}
\hline Galur & $\begin{array}{l}\text { Tinggi Tanaman } \\
(\mathrm{cm})\end{array}$ & $\begin{array}{c}\text { Jumlah Anakan } \\
\text { (Batang) Maksimum }\end{array}$ & $\begin{array}{l}\text { Jumlah Anakan } \\
\text { (Batang) Produktif }\end{array}$ & $\begin{array}{l}\text { Umur Berbunga Panen } \\
\text { (HST) Berbunga }\end{array}$ & Panen \\
\hline G1 & 105 & $7.67^{b}$ & $5.67^{\mathrm{b}}$ & $71.33^{\mathrm{b}}$ & $103.00^{b}$ \\
\hline G3 & 118,33 & $11.00^{\mathrm{b}}$ & $7.67^{b}$ & $74.67^{\mathrm{b}}$ & $107.33^{b}$ \\
\hline G4 & 103,33 & $14.67^{\mathrm{b}}$ & $15.33^{\mathrm{a}}$ & $73.67^{\mathrm{b}}$ & $107.00^{b}$ \\
\hline G6 & 118,33 & $10.00^{b}$ & $8.00^{\mathrm{b}}$ & $74.00^{\mathrm{b}}$ & $107.33^{b}$ \\
\hline G7 & 110,67 & $15.00^{\mathrm{a}}$ & $7.67^{\mathrm{b}}$ & $72.67^{\mathrm{b}}$ & $107.33^{b}$ \\
\hline G8 & 114,00 & $13.67^{\mathrm{b}}$ & $7.00^{b}$ & $72.33^{b}$ & $107.00^{b}$ \\
\hline G17 & 115,67 & $12.00^{\mathrm{b}}$ & $9.67^{\mathrm{b}}$ & $73.67^{\mathrm{b}}$ & $106.67^{b}$ \\
\hline $\mathrm{G} 20$ & 108,33 & $10.00^{b}$ & $10.33^{b}$ & $74.00^{\mathrm{b}}$ & $105.33^{b}$ \\
\hline $\mathrm{G} 23$ & 113,33 & $10.00^{b}$ & $10.00^{b}$ & $72.00^{b}$ & $107.00^{b}$ \\
\hline G45 & 118,33 & $10.67^{\mathrm{b}}$ & $10.00^{b}$ & $80.00^{\mathrm{a}}$ & $114.00^{\mathrm{a}}$ \\
\hline G53 & 112,67 & $10.67^{b}$ & $9.67^{\mathrm{b}}$ & $71.00^{\mathrm{c}}$ & $107.00^{b}$ \\
\hline
\end{tabular}

Keterangan: Angka diikuti dengan huruf yang berbeda dalam kolom yang sama menunjukkan perbedaan pada taraf $5 \%$

\section{Jumlah Anakan (anakan/rumpun)}

Meningkatnya jumlah anakan menyebabkan jumlah daun akan meningkat sehingga potensi fotosintat yang merupakan salah satu penyusun organ tanaman juga meningkat, Sesuai dengan pendapat Jhonson (1978), bahwa dengan bertambahnya luas daun menyebabkan bertambahnya aktifitas fotosintesis, sehingga pertumbuhan tanaman akan lebih cepat. Hasil pengamatan menunjukkan bahwa jumlah anakan galur padi pasang surut G7 menunjukkan pertambahan jumlah yang berbeda nyata dengan galur lainnya. Hal ini menunjukkan bahwa galur G7 merupakan galur yang memiliki kemampuan adaptasi terhadap lingkungan pasang surut kabupaten Rokan Hilir. Ritonga dan Ulpah (2016) menyatakan bahwa kesanggupan dalam membentuk anakan yang baik menjamin jumlah anakan per satuan luas meskipun beberapa tanaman mati pada stadia awal pertumbuhan. Anakan tegak menghasilkan penyebaran cahaya yang lebih baik. Umumnya tanaman padi memproduksi anakan lebih sedikit di musim kemarau dari pada di musim hujan.

\section{Jumlah Anakan Produktif (anakan/rumpun)}

Anakan produktif per rumpun atau per satuan luas merupakan penentu terhadap jumlah malai dengan demikian anakan produktif merupakan salah satu komponen hasil yang berpengaruh langsung terhadap tinggi rendahnya hasil gabah (Simanulang, 2001). Suatu galur dapat dikatakan adaptif apabila dapat tumbuh baik pada wilayah penyebarannya, dengan produksi yang tinggi dan stabil, mempunyai nilai ekonomis tinggi, dapat diterima masyarakat dan berkelanjutan (Somaatmadja, 1995 
dalam Susilawati et al., 2010). Hasil pengamatan lapang menunjukkan bahwa G4 mampu menghasilkan jumlah anakan produktif berbeda nyata dengan galur lainnya. Hal ini menunjukkan bahwa Galur G4 yang memiliki kemampuan metabolisme yang baik sehigga fotosintat yang dihasilkan oleh daun dimanfaatkan sebagian besar untuk membentuk anakan produkktif. Anakan produktif dipengaruhi oleh interaksi genetik dan lingkungan tumbuhnya. Pembentukan anakan produktif sangat menentukan jumlah malai dari tanaman padi. Makin banyak anakan produktif makin banyak jumlah malai. Hasil penelitian Yoshida (1981) kemampuan suatu galur tanaman terhadap cekaman ditentukan oleh kemampuan tanaman membentuk ruas batang yang mengefisienkan penggunaan air melalui mekanisme penurunan jumlah transpirasi dan optimalisasi distribusi asimilat ke anakan untuk pembentukan malai.

\section{Umur Berbunga (hari) dan Panen (hari)}

Hasil pengamatan terhadap parameter umur berbunga tanaman menunjukkan galur G45 (80 HST) menunjukkan perbedaan yang nyata dengan galur $\mathrm{G} 53$ (71 HST) dan G 1 (71,33 HST), namun demikian galur G1 tidak berbeda nyata dengan galur $\mathrm{G} 3,4,6,7,8,17,20$ dan $\mathrm{G}$ 23. Umur berbunga G45 lebih panjang. Beragamnya umur berbunga dan umur panen galur/varietas padi yang diuji disebabkan beragamnya pertumbuhan pada fase vegetatif dan genetartif dari masingmasing galur yang juga disebabkan oleh faktor genetik dari suatu tanaman (De Datta, 1982 dalam Endrizal dan Jumakir, 2005). Selain itu juga ditentukan oleh kondisi lingkungan seperti suhu dan intensitas cahaya. Intensitas cahaya yang tinggi dalam waktu yang panjang akan menyebabkan tanaman menghsilkan fotosintat dalam jumlah besar untuk pertumbuhan dan perkembangan tanaman serta merangsang tanaman untuk memasuki fase generative secara lebih cepat yang ditandai dengan keluarnya bunga. Tanaman padi tidak akan memasuki masa reproduktif jika pertumbuhan vegetatifnya belum selesai dan belum mencapai tahapan yang matang untuk berbunga.

Umur tanaman ratun yang lebih pendek dibandingkan tanaman utama, disebabkan ratun memiliki fase pertumbuhan yang berbeda dengan tanaman utama. Pada tanaman utama terdapat tiga fase pertumbuhan yaitu fase vegetatif, reproduktif dan pemasakan, sedangkan pada ratun hanya terdapat dua fase, yaitu fase reproduktif dan pemasakan. Kedua fase pertumbuhan pada ratun umumnya berlangsung sama pada semua genotipe padi. Fase yang lebih pendek disebabkan munculnya anakan ratun sering diikuti atau bersamaan dengan keluarnya malai atau bunga. Vergara (1995) menyatakan umur tanaman ratun akan berada pada kisaran 65 hari yaitu selama 35 hari untuk fase reproduktif dan 30 hari untuk fase pemasakan.

Terkait dengan penyerapan hara, pada tahap awal pertumbuhan padi local mengabsorbsi $\mathrm{N}$ lebih cepat dan banyak, sehingga pertumbuhan vegetatif lebih tinggi, tetapi jumlah anakan yang dihasilkan rendah dan tanaman mudah mengalami kerebahan (Doberman dan Fairhurst, 2000)

\section{Umur Berbunga (hari) dan Panen (hari)}

Pengaruh suhu terhadap pertumbuhan tanaman sangat besar. Pada suhu yang rendah umur tanaman makin panjang, karena pada suhu yang rendah proses metabolisme tanaman makin lambat sehingga berpengaruh terhadap umur berbunga. Faktor lain yang mempengaruhi pembungaan adalah lamanya penyinaran, makin sedikit tanaman mendapat sinar matahari makin lambat umur berbunga. Pada umumnya padi yang ditanam di dataran tinggi umurnya panjang disebabkan karena suhu dan intensitas cahaya matahari yang tinggi Pada musim kemarau suhu cenderung meningkat, kondisi ini sangat 
berpengaruh terhadap pertumbuhan pada fase generatif, suhu yang rendah menyebabkan pembungaan padi terhambat sehingga umur padi makin panjang.

Pertumbuhan tanaman padi dapat dipengaruhi oleh suhu dan intensitas cahaya. Kondisi iklim yang sesuai selama pertumbuhan akan merangsang tanaman untuk berbunga. Tanaman padi tidak akan memasuki masa reproduktif jika pertumbuhan vegetatifnya belum selesai dan belum mencapai tahapan yang matang untuk berbunga. Beragamnya umur berbunga dan umur panen galur/varietas padi yang diuji disebabkan beragamnya pertumbuhan pada fase vegetatif dan genetartif dari masing-masing galur. Lamanya fase pertumbuhan vegetatif merupakan penyebab perbedaan umur tanaman yang juga disebabkan oleh faktor genetik dari suatu tanaman (De Datta, 1982 dalam Endrizal dan Jumakir, 2005).

\section{Panjang Malai (cm), Gabah Bernas (butir), Berat Seribu Butir (gram)}

Panjang malai merupakan interaksi antara factor genetis dan lingkungan. Panjang malai merupakan salah satu komponen hasil yang dapat menentukan produksi, dengan panjang malai diharapkan jumlah gabah per malai semakin banyak. Hasil analisa terhadap parameter panjang malai, gabah bernas, berat seribu butir dapat dilhat bahwa panjang malai terpanjang terdapat pada G53 $(35.33 \mathrm{~cm})$, terendah G45 (26.67). hal ini di duga galur G 53 memiliki genetis panjang malai yang panjang didukung oleh jumlah foto sintat yang memadai untuk membentuk panjang malai termasuk jumlah gabah per malai. Jumlah gabah per malai ini lebih banyak dipengaruhi oleh aktivitas tanaman selama fase reproduktif yaitu dari primordia sampai penyerbukan. Fotosintesa yang terhambat membuat karbohidrat yang dihasilkan rendah. Pratiwi et al. (2009) dalam (Ikhwani et al., 2010) bahwa terdapat hubungan negative antara panjang malai dan jumlah malai, semakin banyak jumlah malai, semakin pendek malainya. Panjang malai yang panjang akan mempengaruhi jumlah gabah yang diperoleh, hal ini diperjelas oleh Tiur (2009), semakin panjang malai berpengaruh terhadap jumlah gabah per malai.

Jumlah gabah bernas ditentukan oleh jumlah fotosimtat dan faktor lingkungan seperti adanya serangan hama dan penyakit yang menyebabkan gabah menjadi hampa. Hasil pengamatan lapang menunjukkan bahwa gabah bernas tertinggi pada G17 (238.00 butir), dan terendah G8 (147.33 butir). Galur yang dikaji tergolong bernas. Tinggi rendahnya persentase gabah bernas per malai disebabkan oleh perbedaan tanggapan dan ketahanan tiap galur terhadap kondisi lingkungan yang kurang menguntungkan terutama pada fase reproduktif dan pemasakan. Semakin tinggi persentase gabah bernas maka semakin rendah persentase gabah hampa.

Jumlah gabah per rumpun sangat ditentukan oleh ketersediaan air pada saat stadia pembentukan bunga. Air yang tidak tersedia mengakibatkan semakin besarnya kegagalan proses penyerbukan dikarenakan semakin banyaknya polen yang mandul. Akan tetapi dalam penelitian ini cekaman kekeringan tidak terjadi pada fase pembungaan, cekaman kekeringan terjadi pada fase vegetatif. Hal ini diduga tanaman pada kondisi kekurangan air sebelum memasuki fase pembungaan, terlebih dahulu mengalami penghambatan proses pertumbuhan vegetatif.

Pada persentase gabah isi per malai pembentukan dan pengisian buah sangat dipengaruhi oleh ketersediaan unsur hara $\mathrm{P}$ dan K. Nitrogen merupakan bagian integral dari klorofil yang sangat berperan dalam peristiwa fotosintesis dan sebagian besar hasil fotosintesis tersebut tersimpan dalam biji (bulir).

Menurut Vergara (1995), penyebab kehampaan bulir diantaranya rebah, kurang intensitas cahaya, serangan penyakit, pemberian pupuk terlalu banyak, suhu 
rendah sedangkan kelembaban tinggi pada masa pembungaan, dan suhu rendah pada saat pembentukan malai. Intensitas cahaya matahari yang rendah dapat menyebabkan jumlah gabah per malai yang sedikit. Lokasi uji adaptasi merupakan bentuk lingkungan yang berbeda dimana keragaman hasil. Dengan adanya lingkungan yang berbeda dapat ditentukan galur padi pasang surut tipe baru yang mampu beradaptasi.

Semakin banyak jumlah gabah bernas dan semakin berat obot 100 butir akan menyebabkan produksi/produktivitas galur semakin tinggi. Bobot 100 butir tertinggi terdapat pada galur G 53 G53 (26.77 gram), terendah G4 (22.63 gram) (Tabel 2).

Tabel 2. Keragaan generatif galur-galur pada tanaman panjang malai (cm), biji bernas (butir), berat 1000 butir (g), ubinan (ton)

\begin{tabular}{|c|c|c|c|c|}
\hline Galur & $\begin{array}{l}\text { Panjang Malai } \\
\text { (cm) }\end{array}$ & $\begin{array}{c}\text { Jumlah Biji Bernas (butir) } \\
\text { Per Malai }\end{array}$ & $\begin{array}{l}\text { Berat } 100 \text { Butir } \\
(\mathrm{g})\end{array}$ & Ubinan (ton) \\
\hline G1 & $33.33^{\mathrm{a}}$ & $168.33^{\mathrm{a}}$ & $24.00^{\mathrm{a}}$ & $2.27^{\mathrm{a}}$ \\
\hline G3 & $33.67^{\mathrm{a}}$ & $183.33^{\mathrm{a}}$ & $23.00^{\mathrm{a}}$ & $2.20^{\mathrm{a}}$ \\
\hline G4 & $34.33^{\mathrm{a}}$ & $155.67^{\mathrm{a}}$ & $22.63^{\mathrm{a}}$ & $2.50^{\mathrm{a}}$ \\
\hline G6 & $29.67^{\mathrm{a}}$ & $178.67^{\mathrm{a}}$ & $28.37^{\mathrm{a}}$ & $2.43^{\mathrm{a}}$ \\
\hline G7 & $33.67^{\mathrm{a}}$ & $175.00^{\mathrm{a}}$ & $26.63^{\mathrm{a}}$ & $2.13^{\mathrm{a}}$ \\
\hline G8 & $31.00^{\mathrm{a}}$ & $147.33^{\mathrm{a}}$ & $24.13^{\mathrm{a}}$ & $1.42^{\mathrm{a}}$ \\
\hline G17 & $32.67^{\mathrm{a}}$ & $238.00^{\mathrm{a}}$ & $26.33^{\mathrm{a}}$ & $2.40^{\mathrm{a}}$ \\
\hline G20 & $33.00^{\mathrm{a}}$ & $236.67^{\mathrm{a}}$ & $26.27^{\mathrm{a}}$ & $2.33^{\mathrm{a}}$ \\
\hline $\mathrm{G} 23$ & $32.00^{\mathrm{a}}$ & $180.33^{\mathrm{a}}$ & $23.27^{\mathrm{a}}$ & $2.33^{\mathrm{a}}$ \\
\hline G45 & $26.67^{\mathrm{a}}$ & $152.67^{\mathrm{a}}$ & $23.23^{\mathrm{a}}$ & $2.40^{\mathrm{a}}$ \\
\hline G53 & $35.33^{\mathrm{a}}$ & $190.00^{\mathrm{a}}$ & $26.30^{\mathrm{a}}$ & $1.76^{\mathrm{a}}$ \\
\hline
\end{tabular}

Keterangan: Angka diikuti dengan huruf yang berbeda dalam kolom yang sama menunjukkan perbedaan

\section{Hasil (ton/ha)}

Analisis ragam terhadap Hasil (ton/ha) ratun menunjukkan berpengaruh nyata terhadap Hasil (ton/ha). Total hasil ratun galur G45, G7,dan G4 berturut-turut 1.79 ton/ha dan 2.50 ton/ha GKG. Hal ini menunjukkan bahwa G45 adalah galur terbaik dan dapat dikatagorikan sebagai galur stabil. Kualitas gabah padi sistem ratun dinilai relatif rendah yang dicirikan oleh tingginya persentase gabah hampa (25$26 \%$ ) dan bulir rusak akibat penyakit busuk bulir, namun kerusakan ini masih lebih rendah disbanding dengan ratun di lahan pasang surut yang menghasilkan 24-46\% gabah hampa (Susilawati dan Purwoko, 2011). Tingginya persen gabah hampa dapat disebabkan oleh kurangnya produksi asimilat ke bulir yang diikuti oleh penuaan, suhu panas selama pengisian bulir dan stress salinitas padi ratun dengan tinggi tunggul jerami $15-20 \mathrm{~cm}$ menghasilkan tanaman yang lebih tinggi dengan malai lebih panjang serta gabah hampa yang lebih sedikit (Vergara et al., 1995; Susilawati dan Purwoko, 2012).

Teknologi ratun yang sudah diperbaiki dapat dijadikan solusi bagi petani pasang surut yang masih enggan melaksanakan penanaman lebih dari dua kali setahun sehingga mereka tetap dapat berpartisipasi dalam program peningkatan produksi beras Nasional. Hasil ratun yang masih rendah dapat disebabkan oleh galur yang tidak memiliki kemampuan genetik ratun yang baik atau perlakuan budidaya yang kurang tepat. Oleh karena itu seleksi genotipegenotipe berpotensi ratun perlu dilakukan dan harus didukung dengan teknik budidaya yang benar.

\section{KESIMPULAN}

Galur-galur padi ratun yang baik beradaptasi terhadap lahan pasang surut Kabupaten Rokan Hilir pada pertumbuhan 
vegetative pada tinggi tanaman G3 (118.33 $\mathrm{cm})$, jumlah anakan G7 (15.00 batang) Jumlah anakan produktif G4 (15.33 batang) sedangkan untuk pertumbuhan generatif hasil G4 (2.50 ton/ha), panjang malai G53 $(35.33 \mathrm{~cm})$, gabah bernas G17 $(238.00$ gram), berat seribu butir G53 (26,77 gram). Sedangkan G 45 merupakan tanaman ratun hasil yang tertinggi (4.15 ton/ha) dan dapat beradaptasi terhadap lingkungan.

\section{DAFTAR PUSTAKA}

Abdullah S, Suhartatik E, Erdiman, Susilawati, Zaini Z, Jamil A, Made JM, Sasmita P, Buang A, Suwarno, Yuliantoro Bi, Azmi D, Sujinah, Suharna, Ningrum ES. 2015. Panduan teknologi Budidaya Padi Salibu. Badan penelitian dan Pengembangan Pertnian 2015.

Anwar K, Alwi M, Saragih S, Supriyo A, Nazemi D, Sari K. 2001. Karakterisasi dinamika tanah dan air untuk perbaikan pengelolaan lahan pasang surut.

Arsyad DM, Saidi BB, Enrizal, 2014. Pengembangan inovasi pertanian di lahan rawa pasang surut mendukung kedaulatan pangan. Jurnal Pengembangan Inovasi Pertanian. 7(4): 169-176.

Dakhyar N, Hairani A, Indrayati L. 2012. Prospek pengembangan pendataan lahan system surjan di lahan rawa pasang surut. Agrovigor. 5(2): 113-118.

Doberman A, Fairhust T. 2000. Rice nutrient management. potash and phosphate institute of Canada and international rice research intitute. Oxford Geographic Printers Pte Ltd. Canada.

Erdiman, Nieldalina, Misran, Mala Y. 2013. Peningkatan produksi padi dengan teknologi spesifik lokasi Sumatera Barat (teknologi salibu). Laporan Hasil Pengkajian Tahun 2013. BPTP Sumatera Barat.

Ikhwani, Suhartatik E, Makarim AK. 2010. Pengaruh waktu, lama, dan kekeruhan air terhadap pertumbuhan dan hasil padi sawah IR64 - Sub1. Jurnal Pertanian Tanaman Pangan. 29.

Laporan Tahunan Dinas Pertanian Tanaman Pangan dan Hortikultura Provinsi Riau, Tahun 2011.

Liu Z, Bi J, Jiang D, Lin Z, Li X, Ding Y. 2011. Improving rainfall use efficiency of ratoon rice in seasonal drought areas of south China. Agriculture Research in The Arid Areas. 6:25-30.

Liu K, Qin J, Zhang B, Zhao Y. 2012 Physiological trait, yields and nitrogen translocation of ratoon rice in response to different cultiv.

Mishra A, Salokhe VM. 2010. Flooding stress: The effects. Of planting pattern and water regime on root morphology, physiology and grain yield of rice. Jurnal of Agronomy and Crop Science. 196(5): 368-378.

Oad FC, Cruz PS. 2002. Rice varietal screening for ratoonability. Pakistan Journal of Applied Sciences. 2(1): 114119.

Ritonga E, Ulpah S. 2016. Uji adaptasi galur-galur padi lahan pasang surut pada tiga kabupaten di Provinsi Riau. Prosiding Seminar Nasional Lahan Suboptimal 2016, Palembang 20-21 Oktober 2016. Hal:748-763

Simanulang ZA. 2001. Kriteria seleksi untuk sifat agronomis dan mutu. pelatihan dan koordinasi program pemuliaan partifatif (Shuttke Breeding) dan uji multi lokasi. Sukamandi 9-14 April 2001. Balai Penelitian Padi Sukamandi.

Somaatmadja S. 1995. Peningkatan produksi kedelai melalui perakitan varietas. Dalam Susilawati, Uji multilokasi galur harapan dan varietas padi terpilih di lahan pasang surut.

Susilawati, Purwoko BS, Aswidinnoor H, Santosa E. 2010. Keragaan varietas dan galur padi tipe baru Indonesia dalam system ratun. J. Agron. Indonesia. 38:77-84.

Susilawati, Purwoko BS. 2011. Pengujian 
varietas dan dosis pupuk setelah panen untuk meningkatkan potensi ratun-padi di sawah pasang surut. J. Pengkajian dan Pengembangan Teknologi Pertanian. 12(1).

Susilawati, Purwoko SB. 2012. Pengujian varietas dan dosis pupuk untuk meningkatkan pertumbuhan dan hasil ratun-padi di sawah pasang surut.

Sutami. 2004. Potensi hasil galur-galur padi pasang surut terpilih pada Kondisi lahan pasang surut sulfat masam. Agrosains. 6(2):53-57.

Vergara BS. 1995. A Farmer's Primer on Growing Rice. IRRI, Los Banos, Philippines.

Yoshida S. 1981. Fundamentals of Rice Crop Science. International Rice Research Institute. Los Banos, Philippines. 